oxidase, free from fumarylpyruvic acid hydrolyase, from the cells of Pseudomonas ovalis S-5.

2) From the results obtained, the crystalline intermdediate was identified as fumarylpyruvic acid, which was splitted by crude extracts into pyruvic and fumaric acids.

3) Maleylpyruvic acid, the initial product of gentisic acid oxidation, was recognized spectro- photometrically in the reaction mixture using purified enzyme. And the pathway of gentisic acid oxidative metabolism was established.

4) Colorimentric determination of fumarylpyruvic acid is also described.

The authors wish to express their sincere thanks to Honorary Prof. K. Sakaguchi for his continued guidance throughout this research.

[Bull. Agr. Chem. Soc. Japan, Vol. 24, No. 3, p. 261 265, 1960]

\title{
Studies on the Organophosphorus Insecticides
}

\section{Part I. Synthesis and Toxicity of Phosphates Containing Vinyl Radical}

\author{
By Yoshihiko Nishizawa \\ Laboratory of Sumitomo Chem. Co., Lid., Osaka \\ Received May 19, 1959
}

\begin{abstract}
Many phosphates containing vinyl radical such as Phosdrin ${ }^{13}$ were prepared in order to study the correlation between structure and toxicity. From the results obtained it seems certain that in regard of toxicity, it is the carboalcoxy radical rather than the vinyl radical that is necessary and furthermore the toxicity is connected with the atom or the radical linked with the vinyl radical. As a results of these studies, some new toxic phosphates were synthesized.
\end{abstract}

As it is well known, all organophosphorus compounds do not always show toxicity and insecticidal activity but are highly toxic when they have a definite structure.

For instance take Phosdrin ${ }^{1)}$, it is found that the introduction of the carboalcoxy-vinyl radical to the phosphate gives toxic property, though trialkyl phosphates have no toxicity.

Therefore, the studies on the correlation between toxicity and the structure is of a fundamental importance in the application of phos-

1) A.R. Stiles, U.S.P. 2,685,552 (1954). phates for agricultural use.

From studies on the chemical constitution of phosphates containing vinyl radical such as phosdrin, it becomes clear that the thiono-form is not toxic ${ }^{23}$ and the cis-configuration has a higher toxicity than that of the $\operatorname{trans}^{32}$.

So far nothing has been reported on the influences of the substituents in the Phosdrintype phosphates. Therefore, an attempt to study the chemical structure giving toxic property on

2) G. Schrader, BIOS Final Report, No. 714 (1947).

3) J. E. Casida, Science, 122, 497 (1955). 
Table I. The TOXIC Dose of Phosphates $\left(\operatorname{LD}_{50}\right)$

\begin{tabular}{|c|c|c|c|}
\hline No. & Formula & \multicolumn{2}{|c|}{$\begin{array}{ll}\text { Oral Toxicity of Mice } \\
\mathrm{mg} / \mathrm{kg} & \mathrm{Mol} / \mathrm{kg}\end{array}$} \\
\hline I. & $\left(\mathrm{CH}_{3} \mathrm{O}\right)_{2} \mathrm{P}(\mathrm{O}) \mathrm{OC}\left(\mathrm{CH}_{3}\right): \mathrm{CHCOOG}_{2} \mathrm{H}_{5}$ & 7.8 & $3.2 \times 10^{-5}$ \\
\hline II. & $\left(\mathrm{CH}_{3} \mathrm{O}\right)_{3} \mathrm{P}(\mathrm{O}) \mathrm{OC}\left(\mathrm{CH}_{3}\right)(\mathrm{Cl}) \mathrm{CH}(\mathrm{Cl}) \mathrm{COOC}_{2} \mathrm{H}_{5}$ & 22.0 & $7.1 \times 10^{-4}$ \\
\hline III. & $\left(\mathrm{CH}_{3} \mathrm{O}\right)_{2} \mathrm{P}(\mathrm{O}) \mathrm{OC}\left(\mathrm{CH}_{3}\right): \mathrm{CClCOOG}_{2} \mathrm{H}_{5}$ & 60.0 & $2.2 \times 10^{-4}$ \\
\hline IV. & $\left(\mathrm{CH}_{3} \mathrm{O}\right)_{3} \mathrm{P}(\mathrm{O}) \mathrm{OC}\left(\mathrm{CH}_{3}\right): \mathrm{C}\left(\mathrm{C}_{6} \mathrm{H}_{5}\right) \mathrm{COOC}_{2} \mathrm{H}_{5}$ & 32.0 & $1.0 \times 10^{-4}$ \\
\hline V. & 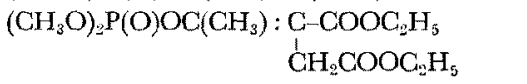 & 125.0 & $3.9 \times 10^{-4}$ \\
\hline
\end{tabular}

Phosdrin was made.

Phosdrin has two characteristic parts, namely, the vinyl and carboalcoxy-radical. Therefore, in these studies, influences of these two radicals on the toxicity were examined one by one.

1) The influence of the vinyl radical

The chlorination of O,O-dimethyl-O-(2-carboethoxy-1-methyl-vinyl)-phosphate (I) proceeded in a smooth way and the dichloro-derivatives (II) prepared were obtained in a good yield. It is clearly shown that two chlorine atoms add to the vinyl radical, because this dichloro-derivative already has no infrared absorption of the vinyl radical (see Fig. 3). The toxicity of this dichlorophosphate (II) is roughly a half-time weaker than the parent phosphate (I) (see Table I). Furthermore, a marked reduction in toxicity occurs when radicals such as halogen (III), phenyl (IV) or carboethoxy-methyl radical (V) are substituted in the $\alpha$-position of the carboethoxyradical of Formula (I) as shown in Table I.

The $\mathrm{C}=\mathrm{C}$ absorption of ethylene in the parent phosphate (I) at $1660 \mathrm{~cm}^{-1}$ shows only a small frequency shift to $1650 \sim 1630 \mathrm{~cm}^{-1}$ with a $\alpha$ substitution (for example, see Figs. 1 and 2.). Though reasons for this shift are not clarified this shift must indicate an elognation of the double bond under the influence of the $\alpha$ substituted atom or radicals.

From the above results it is possible to consider that the substitution of the hydrogen atom of vinyl radical or the saturation of the vinyl radical by chlorine, reduces toxicity; in other words, the vinyl radical has some sensitive influence to toxicity.

2) The influence of the carboalcoxy radical.
In order to study the influence of the carboalcoxy-rdical, O,O-diethyl-O-(1-phenyl-vinyl)phosphate ${ }^{4)}$ containing no carboalcoxy group was prepared according to the following equation:

$$
\begin{gathered}
\left.\left(\mathrm{C}_{2} \mathrm{H}_{5} \mathrm{O}\right)_{3} \mathrm{P}+\underset{\mathrm{COCH}_{2} \mathrm{Br}}{\longrightarrow}-\mathrm{C}_{2} \mathrm{H}_{5} \mathrm{O}\right)_{2} \mathrm{P}(\mathrm{O}) \mathrm{OC}\left(\mathrm{C}_{6} \mathrm{H}_{5}\right)=\mathrm{CH}_{2} \\
(\text { VIII }) \\
+\left(\mathrm{C}_{2} \mathrm{H}_{5} \mathrm{O}\right)_{2} \mathrm{P}(\mathrm{O}) \mathrm{CH}_{2} \mathrm{COC}_{6} \mathrm{H}_{5} \\
\text { (VIIIb) }
\end{gathered}
$$

This process was always acompanied with the keto-phosphate (VIIIb) as the by-product, but it could separate the vinyl-phosphate (VIIIa) from the keto-phosphate (VIIIb) by fractionated distillation just as in the Kreutzkamp meteod ${ }^{5)}$.

As mentioned above, the vinyl radical has some sensitive influence to the toxicity, but toxicity still remains to some extent by upon saturation. In the case of carboalcoxy-radical, the substitution of carboalcoxy-radical by the hydrogen atom or the phenyl-radical counteracts toxicity (see Table II). Therefore as a consequence of these features, it is obvious that the toxicity depends upon the carboalcoxy radical rather than the vinyl radical.

\section{3) The influence of the substitution of carboalcoxy- radical by some new radicals.}

It is very interesting that the substitution of carboalcoxy-radical by chlorine atom shows a slight toxicity (see Table II), though this is not observed in the substitution by hydrogen atom (VIIIa) or phenyl radical (IX).

These results suggest the possibility that new toxic phosphates will be prepared by the sub-

4) Arbuzov, Zhur Abshchim., 4, 834 (1934).

5) N. Kreutzkamp, Ber, 89, 1614 (1956). 


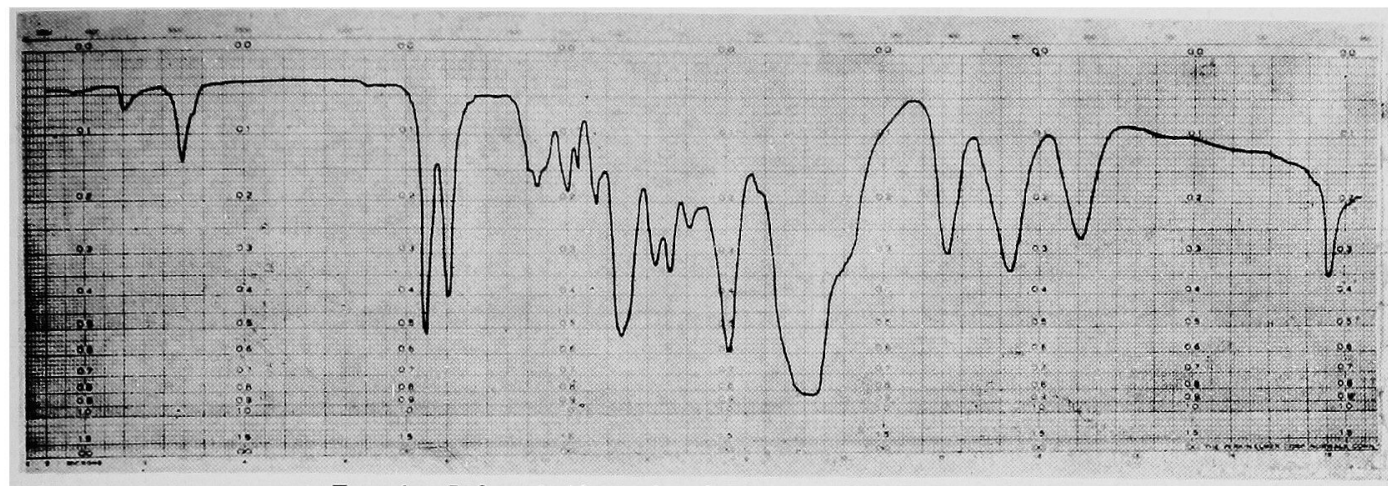

FIG. 1. Infrared Absorption Spectrum of O, O-Dimethyl-O-

(2-carboethoxy-1-methyl-vinyl)-phosphate (I)

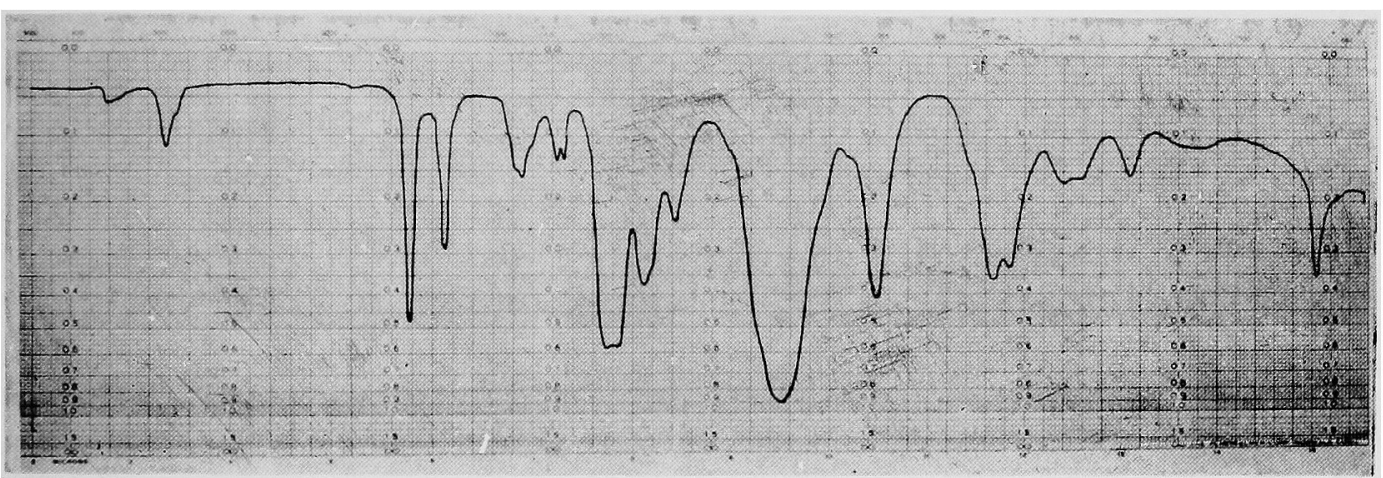

FIG. 2. Infrared Absorption Spectrum of O, O-Dimethyl-O-(2carboethoxy-2-chloro-1-methyl-vinyl)-phosphate (III)

Table II. The Toxic Dose of Phosphates $\left(\mathrm{LD}_{50}\right)$

No. Formula

VI. $\quad\left(\mathrm{CH}_{3} \mathrm{O}\right)_{2} \mathrm{P}(\mathrm{O}) \mathrm{OC}\left(\mathrm{C}_{6} \mathrm{H}_{5}\right): \mathrm{CHCOOC}_{2} \mathrm{H}_{5}$ VII. $\left(\mathrm{C}_{2} \mathrm{H}_{5} \mathrm{O}\right)_{2} \mathrm{P}(\mathrm{O}) \mathrm{OC}\left(\mathrm{C}_{6} \mathrm{H}_{5}\right): \mathrm{CHCOOC}_{2} \mathrm{H}_{5}$

VIIIa. $\quad\left(\mathrm{C}_{2} \mathrm{H}_{5} \mathrm{O}\right)_{2} \mathrm{P}(\mathrm{O}) \mathrm{OC}\left(\mathrm{C}_{6} \mathrm{H}_{5}\right): \mathrm{CH}_{2}$

IX. $\left(\mathrm{CH}_{3} \mathrm{O}\right)_{2} \mathrm{P}(\mathrm{O}) \mathrm{OC}\left(\mathrm{C}_{6} \mathrm{H}_{5}\right): \mathrm{CH}\left(\mathrm{C}_{6} \mathrm{H}_{5}\right)$

X. $\quad\left(\mathrm{CH}_{3} \mathrm{O}\right)_{2} \mathrm{P}(\mathrm{O}) \mathrm{OC}\left(\mathrm{C}_{6} \mathrm{H}_{5}\right): \mathrm{CHCl}$

XI. $\left(\mathrm{C}_{2} \mathrm{H}_{5} \mathrm{O}\right)_{2} \mathrm{P}(\mathrm{O}) \mathrm{OC}\left(\mathrm{C}_{6} \mathrm{H}_{5}\right): \mathrm{CHCl}$
Oral Toxicity of Mice $\mathrm{mg} / \mathrm{kg} \quad \mathrm{Mol} / \mathrm{kg}$

$\begin{array}{rc}11.7 & 3.9 \times 10^{-5} \\ 24.0 & 7.3 \times 10^{-5} \\ >1000 & - \\ >1000 & - \\ 240.0 & 9.1 \times 10^{-4} \\ 138.0 & 4.8 \times 10^{-4}\end{array}$

Table III. The Toxic Dose of Phosphates $\left(\mathrm{LD}_{50}\right)$

No.

XII. $\left(\mathrm{CH}_{3} \mathrm{O}\right)_{2} \mathrm{P}(\mathrm{O}) \mathrm{OC}\left(\mathrm{C}_{6} \mathrm{H}_{5}\right): \mathrm{CH}\left(\mathrm{OC}_{6} \mathrm{H}_{4} \mathrm{NO}_{2}\right)$

XIII. $\quad\left(\mathrm{C}_{2} \mathrm{H}_{5} \mathrm{O}\right)_{2} \mathrm{P}(\mathrm{O}) \mathrm{OC}\left(\mathrm{C}_{6} \mathrm{H}_{5}\right): \mathrm{CH}\left(\mathrm{OC}_{6} \mathrm{H}_{4} \mathrm{NO}_{2}\right)$

XIV. $\quad\left(\mathrm{CH}_{3} \mathrm{O}\right)_{2} \mathrm{P}(\mathrm{O}) \mathrm{OCH}: \mathrm{CCl}\left(\mathrm{OC}_{6} \mathrm{H}_{4} \mathrm{NO}_{2}\right)$

XV. $\quad\left(\mathrm{CH}_{3} \mathrm{O}\right)_{2} \mathrm{P}(\mathrm{O}) \mathrm{OC}\left(\mathrm{CH}_{3}\right): \mathrm{CHCOCH}_{3}$

XVI. $\left.\quad\left(\mathrm{G}_{2} \mathrm{H}_{5} \mathrm{O}\right)_{2} \mathrm{P}(\mathrm{O}) \mathrm{OC}\left(\mathrm{CH}_{3}\right): \mathrm{CHCOCH}_{3}{ }^{6}\right)$
Oral Toxicity of Mice $\mathrm{mg} / \mathrm{kg} \quad \mathrm{Mol} / \mathrm{kg}$

$42.0 \quad 1.2 \times 10^{-4}$

$16.6 \quad 4.2 \times 10^{-5}$

$20.0 \quad 6.2 \times 10^{-5}$

$55.0 \quad 2.6 \times 10^{-4}$

$24.0 \quad 1.0 \times 10^{-4}$ 
Table IV. The Yield and the Physical and the Microanalytical Data of New Phosphates

\begin{tabular}{|c|c|c|c|c|c|c|c|c|c|}
\hline No. & Formula & $\begin{array}{c}\text { Yield } \\
\%\end{array}$ & ${ }^{\circ} \mathrm{C}$ & mmHg & $n_{\mathrm{D}} / t^{\circ} \mathrm{C}$ & $\begin{array}{l}\text { Phosph } \\
\text { Calcd. }\end{array}$ & $\begin{array}{l}\text { orus } \% \\
\text { Found. }\end{array}$ & $\begin{array}{l}\text { Chlo } \\
\text { Calcd. }\end{array}$ & $\begin{array}{l}\text { ze or } \\
\text { ound. }\end{array}$ \\
\hline I. & $\left(\mathrm{CH}_{3} \mathrm{O}\right)_{2} \mathrm{P}(\mathrm{O}) \mathrm{OC}\left(\mathrm{CH}_{3}\right): \mathrm{CHCOOC}_{2} \mathrm{H}_{5}$ & 58 & 118 & 1.0 & $1.4450 / 28$ & 13.0 & 12.8 & - & - \\
\hline III. & $\left(\mathrm{CH}_{3} \mathrm{O}\right)_{2} \mathrm{P}(\mathrm{O}) \mathrm{OC}\left(\mathrm{CH}_{3}\right): \mathrm{CClCOOC}_{2} \mathrm{H}_{5}$ & 73 & $138 \sim 140$ & 0.8 & $1.4620 / 26$ & 11.4 & 11.8 & 13.03 & 13.21 \\
\hline IV. & $\left(\mathrm{CH}_{3} \mathrm{O}\right)_{2} \mathrm{P}(\mathrm{O}) \mathrm{OC}\left(\mathrm{CH}_{3}\right): \mathrm{C}\left(\mathrm{C}_{6} \mathrm{H}_{5}\right) \mathrm{COOC}_{2} \mathrm{H}_{5}$ & 66 & $147 \sim 152$ & 0.35 & $1.5070 / 23.5$ & 9.8 & 10.0 & - & - \\
\hline V. & $\left(\mathrm{CH}_{3} \mathrm{O}\right)_{2} \mathrm{P}(\mathrm{O}) \mathrm{OC}\left(\mathrm{CH}_{3}\right): \underset{\mathrm{CH}_{2} \mathrm{COOOC}_{2} \mathrm{H}_{5}}{\mathrm{CCOOO}_{5}}$ & 42 & 160 & 1.0 & $1.4549 / 26.5$ & 9.6 & 9.3 & - & - \\
\hline VI. & $\left(\mathrm{CH}_{3} \mathrm{O}\right)_{2} \mathrm{P}(\mathrm{O}) \mathrm{OC}\left(\mathrm{C}_{6} \mathrm{H}_{5}\right): \mathrm{CH}$ & 65 & $149 \sim 151$ & 0.65 & & 10.3 & 10.6 & - & - \\
\hline VII. & $\left(\mathrm{C}_{2} \mathrm{H}_{5} \mathrm{C}\right.$ & 69 & $151 \sim 153$ & 0.35 & $1.5140 / 22.5$ & 9.5 & 9.7 & - & - \\
\hline IX. & $\left(\mathrm{CH}_{3} \mathrm{O}\right)_{2} \mathrm{P}(\mathrm{O}) \mathrm{OC}(\mathrm{C}$ & 42 & $165 \sim 166$ & 0.15 & $1.5795 / 25$ & 10.2 & 10.4 & - & - \\
\hline $\mathbf{x}$. & $\left(\mathrm{CH}_{3} \mathrm{O}\right)_{2} \mathrm{P}(\mathrm{O}) \mathrm{O}$ & 51 & $125 \sim 135$ & 0.3 & $2 / 28$ & 11.8 & 11.7 & 13.52 & 13.26 \\
\hline XI. & $\left(\mathrm{C}_{2} \mathrm{H}_{5} \mathrm{O}\right)_{2} \mathrm{P}(\mathrm{O}) \mathrm{OC}(\mathrm{C}$ & 61 & $\sim 139$ & 0.4 & $1.5163 / 24$ & 10.7 & 11.0 & 12.22 & 12.51 \\
\hline $\mathrm{XV}$. & $\left(\mathrm{CH}_{3} \mathrm{O}\right)_{2} \mathrm{P}(\mathrm{O}) \mathrm{OC}\left(\mathrm{CH}_{3}\right)$ & 55 & $99 \sim 100$ & 0.8 & $1.4500 / 25.5$ & 14.9 & 15.3 & - & - \\
\hline VI. & $\left(\mathrm{C}_{2} \mathrm{H}_{5} \mathrm{O}\right)_{2} \mathrm{P}(\mathrm{O}) \mathrm{OC}\left(\mathrm{CH}_{3}\right): \mathrm{CHCOCH}_{3}$ & 68 & $101 \sim 103$ & 1.0 & $1.4565 / 19.5$ & 13.1 & 13.2 & - & - \\
\hline
\end{tabular}

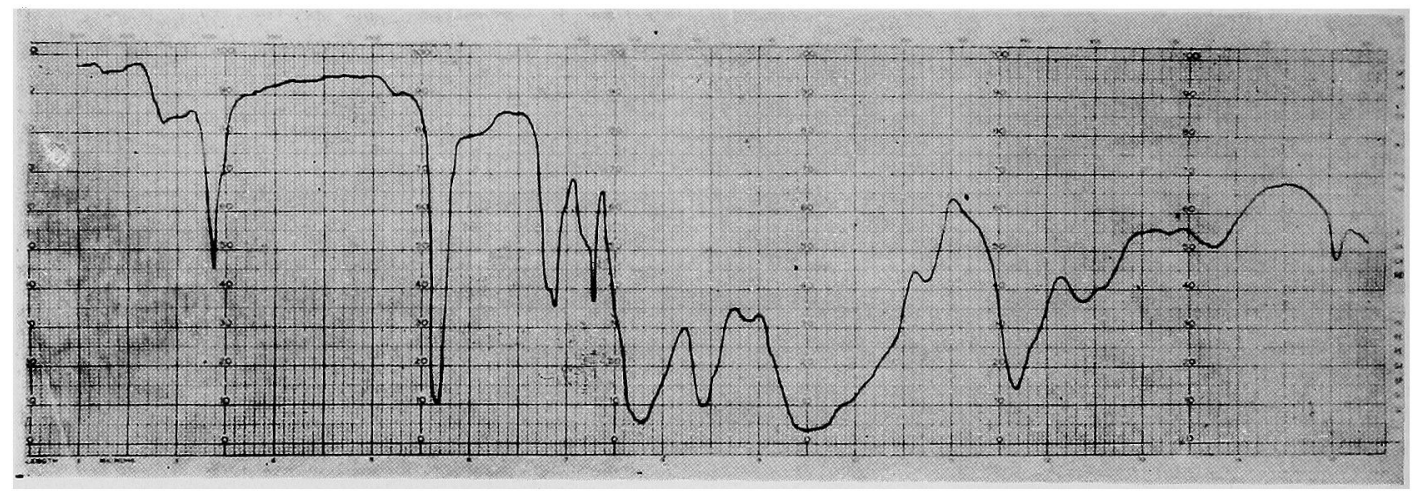

FIG. 3. Infrared Absorption Spectrum of O, O-Dimethyl-O-(1, 2dichloro-1-methyl-2-carboethoxy-ethyl)-phosphate (II)

stitution of carboalcoxy-radical by some other atom or radical. Thus, an attempt to link the substituents such as p-nitrophenoxy- or acetylradical with the vinyl radical was made in accordance with the following equations :

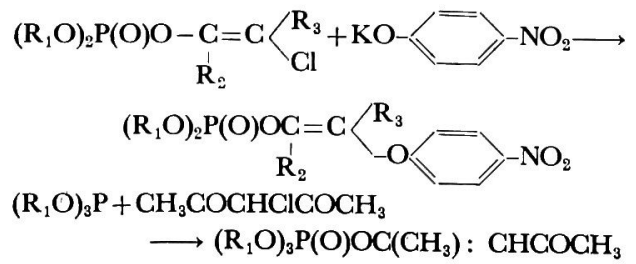

In practice, it was found that these phosphates (XII, XIII, XIV, XV and XVI) have a high toxicity as shown in Table III.

\section{EXPERIMENTAL}

1) The preparation of phosphates containing vinyl radical.

The new phosphates were prepared by the reaction of trialkyl-phosphite and $\boldsymbol{\alpha}$-halo or $\boldsymbol{\alpha}, \boldsymbol{\alpha}$--dihalo-keto-compounds in absolute ether or benzene. The yield, physical and the microanalytical data are shown in Table IV, respectively.

2) The chlorination of 0,0-dimethyl-0-(1-methyl2-carboethoxy-vinyl)-phosphate (I)

Sixteen grams $(0.05 \mathrm{~mol})$ of O,O-dimethyl-O-(1-methyl2-carboethoxy-vinyl)-phosphate (I) was added with stirring to $30 \mathrm{ml}$ of chloroform, saturated with chlorine at $10^{\circ} \mathrm{C}$, 
with sufficient cooling to keep the temperature at $0^{\circ} \mathrm{C}$.

After standing over night at room temperature, chloroform was evaporated under a reduced pressure and the residual oil was distilled. The fraction boiled at $133 \sim$ $135^{\circ} \mathrm{C} / 0.88 \mathrm{mmHg} . n_{\mathrm{D}}^{27} 1.4545$, Yield $9.0 \mathrm{~g}(58.1 \%)$

Anal. Calcd. for $\mathrm{C}_{8} \mathrm{H}_{15} \mathrm{O}_{6} \mathrm{Cl}_{3} \mathrm{P} ; \mathrm{P}, 10.1 ; \mathrm{Cl}, 22.98 \%$ Found $\quad ; \mathrm{P}, 9.5 ; \mathrm{Cl}, 22.73 \%$.

3) The Synthesis of 0,0-dimethyl-O-(1-phenyl-2-pnitro-phenoxy-vinyl)-phosphate (XII).

The phosphate (XII) was prepared by adding $17.7 \mathrm{~g}$ $(0.1 \mathrm{M})$ of $p$-nitrophenol potassium salt into $70 \mathrm{ml}$ chlorobenzene containing $26.0 \mathrm{~g}(0.1 \mathrm{M})$ of $\mathrm{O}, \mathrm{O}$-dimethyl-O-(1phenyl-2-chloro-vinyl)-phosphate $(\mathrm{X})$. The mixture was heated to $120^{\circ} \mathrm{C}$ for $8 \mathrm{hrs}$. After washing with water and drying with anbydrous sodium sulfate, chlobenzene was evaporated under reduced pressure. Fractionation of the residual oil gave $10.0 \mathrm{~g}(27.4 \%)$ of $\mathrm{O}$, O-dimethyl$\mathrm{O}$-(l-phenyl-2-p-nitrophenoxy-vinyl)-phosphate $(\mathrm{X}) ; \mathrm{b}$. p. $145 \sim 150^{\circ} \mathrm{C} / 0.7 \mathrm{mmHg} . n_{\mathrm{J}}^{56} 1.5488$

Anal. Calcd. for $\mathrm{C}_{16} \mathrm{H}_{16} \mathrm{O}_{7} \mathrm{NP} ; \mathrm{P}, 8.5 ; \mathrm{N}, 3.82 \%$

$$
\text { Found } \quad ; \mathrm{P}, 9.0 ; \mathrm{N}, 3.66 \%
$$

O,O-Diethyl-derivative (XIII) was prepared in the same manner as above, from $29.0 \mathrm{~g}(0.1 \mathrm{M})$ of O,O-diethyl-O-

6) A.N. Pudovik, Doklady Akad. Natkk S.S.S.R., 105, 735 (1955); Chem. Abstr, 50, $11230 \mathrm{~g}$ (1956). (1-phenyl-2-chloro-vinyl)-phosphate (XI). This was distilled and the fraction boiling at $146 \sim 150^{\circ} \mathrm{C} / 0.44 \mathrm{mmHg}$ $n_{\mathrm{D}}^{38} 1.5303$, weighted $15.0 \mathrm{~g}(38.1 \%)$

Anal. Calcd. for $\mathrm{C}_{18} \mathrm{H}_{20} \mathrm{O}_{7} \mathrm{NP} ; \mathrm{P}, 7.9 ; \mathrm{N}, 3.56 \%$ Found $\quad ; \mathrm{P}, 8.1 ; \mathrm{N}, 3.66 \%$

Likewise as above $\mathrm{O}, \mathrm{O}$-Dimethyl-O-(2-chloro-2-p-nitrophenoxy-vinyl)-phosphate (XIV) was also prepared from $17.7 \mathrm{~g}(0.1 \mathrm{M})$ of $p$-nitrophenol potassium salt and $44.1 \mathrm{~g}$ (0.2M) of O,O-dimethyl-O-(2, $2^{\prime}$-dichloro-vinyl)-phosphate (D. D. V. P.). This was distilled and the fraction bolling at $155 \sim 160^{\circ} \mathrm{C} / 0.66 \mathrm{mmHg} n_{\mathrm{D}}^{28} 1.5344$ weighted $13.7 \mathrm{~g}$ (42\%6 from $p$-nitrophenol potassium salt)

Anal. Calcd. for $\mathrm{C}_{10} \mathrm{H}_{11} \mathrm{O}_{7} \mathrm{CINP} ; \mathrm{P}, 9.6 ; \mathrm{N}, 4.33$; Cl, 10.97\%

Found $\quad ; \mathrm{P}, 9.0 ; \mathrm{N}, 4.16$;

$\mathrm{Cl}, 10.63 \%$

The author wishes to express his sincere thanks to Dr. Ooi for the infrared absorption spectrum, Mr. Kadota for observation of the toxicity, Mr. Iwai for performing microanalysis.

The author is also much indebted to $\mathrm{Mr}$. Nakagawa for his earnest experimental assistance. 